\title{
PENERAPAN MANAJEMEN PENINGKATAN MUTU DI MADRASAH ALIYAH NEGERI KABUPATEN KAMPAR
}

\author{
Mardalisnar \\ Mahasiswa Manajemen Pendidikan Islam PPs UIN Suska Riau \\ mardalisnar@gmail.com \\ Muslim Afandi \\ Dosen Prodi Manajemen Pendidikan Islam PPs UIN Suska Riau \\ muslim.affandi@uin-suska.ac.id \\ Idris \\ Dosen Prodi Manajemen Pendidikan Islam PPs UIN Suska Riau \\ idris@uin-suska.ac.id
}

\begin{abstract}
Abstrak
Penelitian ini bertujuan untuk mengetahui penerapan manajemen peningkatan mutu di Madrasah Aliyah Negeri Kabupaten Kampar" Rumusan Masalah yang diajukan adalah: 1) Bagaimana Penerapan Manajemen peningkatan mutu di Madrasah Aliyah Negeri Kabupaten Kampar? 2) Apa sajakah faktor yang menunjang Penerapan Manajemen peningkatan mutu di Madrasah Aliyah Negeri Kabupaten Kampar? 3) Apa sajakah faktor yang menghambat Penerapan Manajemen peningkatan mutu di Madrasah Aliyah Negeri Kabupaten Kampar? Analisa yang digunakan dalam penelitian ini adalah analisa kualitatif, yaitu analisis dan interpretasi dilakukan secara kritis. Dengan menggunakan teknik deskriptif analitis yaitu mendeskripsikan maupun mengklasifikasikan data dan kemudian disusul interpretasi terhadap hasil pemikiran. Hasil penelitian yang dapat penulis identifikasi adalah; Pertama, Untuk tercapainya peningkatan mutu pendidikan dan layanan yang cepat, tepat dan efesien perlu terus diusahakan adanya keteladanan, kesadaran dan kerjasama yang baik dari masing-masing jajaran MAN seKabupaten kampa, bahwa apapun yang ada di MAN se-Kabupaten kampar harus menjadi yang terbaik, sebagai manajer kepala MAN Negeri di Kabupaten Kampar telah mampu dalam meningkatkan kompetensi guru di lingkungan MAN mampu mengelola lembaga pendidikan tersebut sehingga tercapai tujuan yang diinginkan. sebagai leader/ pemimpin, kepemimpinan kepala MAN menjadi teladan bagi warga MAN dan mampu menggerakkan warga MAN dalam bekerjasama untuk mencapai tujuan pendidikan Kedua, Faktor yang menunjang Penerapan Manajemen peningkatan mutu di Madrasah Aliyah Negeri Kabupaten Kampar program peningkatan kualifikasi guru, peningkatan personil madrasah secara moril atau dalam hal keagamaan, kekeluargaan antara guru dan masyarakat sekitar yang erat, serta sumbangsih masyarakat sekitar madrasah dalam meningkatkan kualitas madrasah secara menyeluruh. Sedangkan faktor penghambat dalam mencapai keberhasilan kompetensi guru di lingkungan MAN Negeri di Kabupaten Kampar tersebut tidak ada karena sarana prasarana untuk peningkatan bakat siswa, sumber daya manusia atau guru sudah lengkap.
\end{abstract}

Kata Kunci: Penerapan, Manajemen Peningkatan Mutu, Total Quality Manajemen (TQM).

\section{PENDAHULUAN}

Kepemimpinan adalah proses mempengaruhi aktifitas kelompok yang terorganisir untuk mencapai sasaran ${ }^{1}$. Dalam lembaga pendidikan islam, sumber

\footnotetext{
${ }^{1}$ Behling dkk, dalam materi pelatihan keterampilan manajerial SPMK. Tersedia:HTTP//kmpk.ugm.ac.id./data/SPMKK/5aKEPEMIMPINAN (revDes'02. 1984,. HAL.46
}

daya manusia adalah tenaga atau personel kependidikan yang terdiri dari kepala sekolah, tenaga pendidik, pegawai tata usaha sampai dengan pesuruh ${ }^{2}$. Untuk mewujudkan sebuah pendidikan yang baik

${ }^{2}$ Husbullahal. Otonomi Pendidikan: Kebijakan Otonomi Daerah dan Implikasinya terhadap Penyelenggaraan Pendidikan. Jakarta: PT. Rajagrafindo Persada 2006. hal. 111 
dan berkualitas, maka diperlukan adanya komponen yang mendukung, yang salah satunya adalah kepala Madrasah, karena keberadaan kepala Madrasah sangat berpengaruh terhadap semua sumber daya pendidikan yang ada. Berbagai sumber daya pendidikan seperti, sarana dan prasarana, biaya, teknologi, informasi, siswa dan orang tua siswa dapat berfungsi dengan baik apabila guru memiliki kemampuan yang baik pula dalam menggunakan semua sumber daya yang ada.

Dalam menjalankan berbagai tugasnya setiap kepala Madrasah tentu tidak mempunyai kemampuan yang sama, baik dalam hal menata manajemen Madrasah ataupun dalam kemampuan personal kepala Madrasah. Kegiatan kepengawasan atau teknik supervisi yang merupakan kompetensi yang harus dimiliki oleh seorang kepala Madrasah belum mendapat bagian yang proporsional dalam agenda kegiatan seorang kepala Madrasah. Padahal supervisi ini sangat menunjang bagi pengembangan tenaga kependidikan yaitu guru di organisasi permadrasahan.

Pendidikan yang berkualitas menjadi dambaan masyarakat, bangsa dan Negara. Namun saat ini dunia pendidikan di Indonesia belum sepenuhnya dapat memenuhi harapan masyarakat. Fenomena itu ditandai dari rendahnya mutu lulusan, penyelesaian masalah pendidikan yang tidak sampai tuntas, atau cenderung tambal sulam, bahkan lebih berorintasi proyek. Akibatnya, seringkali hasil pendidikan mengecewakan masyarakat. Kualitas lulusan pendidikan kurang sesuai dengan kebutuhan pasar tenaga kerja dan pembangunan, baik industri, perbankan, telekomunikasi, maupun pasar tenaga kerja sektor lainnya yang cenderung menggugat eksistensi sekolah. bahkan Sumber Daya Manusia (SDM) yang disiapkan melalui pendidikan sebagai generasi penerus belum sepenuhnya memuaskan bila dilihat dari

3 Syafarudin, Manajemen Mutu Terpadu dalam Pendidikan, (Jakarta: Grasindo, 2002) segi akhlak, moral, dan jati diri bangsa dalam kemajemukan budaya bangsa.

Kondisi tersebut menyebabkan sebagian masyarakat menjadi pesimis terhadap sekolah. ada anggapan bahwa pendidikan tidak lagi mampu menciptakan mobilitas sosial, mereka secara vertikal, karena sekolah tidak menjanjikan pekerjaan yang layak. Sekolah kurang menjamin masa depan anak yang lebih baik. Sebagaimana diungkapkan dimuka, perubahan paradigma baru pendidikan kepada mutu (quality oriented) merupakan salah satu strategi untuk mencapai pembinaan keunggulan pribadi anak ${ }^{3}$. Dalam konteks bangsa Indonesia, peningkatan mutu pendidikan merupakan sasaran pembangunan dibidang pendidikan nasional dan merupakan bagian integral dari upaya peningkatan kualitas manusia Indonesia secara menyeluruh ${ }^{4}$.

Madrasah Aliyah Negeri Kabupaten Kampar sebagai lembaga pendidikan Islam setingkat dengan SMA dan SMK di Kabupaten Kampar dengan jumlah penduduk muslim yang mayoritas, termotivasi untuk memberikan pendidikan yang berkualitas dengan senantiasa melakukan upaya peningkatan mutu pendidikan dengan menerapkan manajemen berbasis Madrasah melalui pendekatan sistem manajemen mutu terpadu atau biasa disebut dengan Total Quality Manajement (TQM).

Tujuan yang ingin dicapai dalam penelitian ini adalah:

a. Tujuan secara khusus dari penelitian ini adalah sebagai pemenuhan kewajiban dalam penyelesaian program perkuliahan. Sedangkan tujuan yang lebih luasnya adalah berupaya memberikan gambaran, pengertian dan pemahaman yang cukup lengkap tentang:

b. Untuk mengetahui penerapan manajemen peningkatan mutu di

${ }^{4}$ E. Mulyasa, Menjadi Kepala Sekolah Profesional dalam Menyukseskan MBS dan KBK (Bandung: PT. Remaja Rosdakarya, 2005), hal.31 
Madrasah Aliyah Negeri Kabupaten Kampar

c. Untuk mengetahui faktor-faktor yang mendukung penerapan manajemen peningkatan mutu di Madrasah Aliyah Negeri Kabupaten Kampar.

d. Untuk mengetahui faktor-faktor yang menghambat penerapan manajemen peningkatan mutu di Madrasah Aliyah Negeri Kabupaten Kampar.

Menurut J.S Badudu dan Sutan Mohammad Zain, penerapan adalah hal, cara atau hasil ${ }^{5}$. Adapun menurut Lukman Ali, penerapan adalah mempraktekan, memasangkan ${ }^{6}$. Berdasarkan pengertian tersebut dapat disimpulkan bahwa penerapan merupakan sebuah tindakan yang dilakukan baik secara individu maupun kelompok dengan maksud untuk mencapai tujuan yang telah dirumuskan.

Menurut Usman, penerapan (implementasi) adalah bermuara pada aktivitas, aksi, tindakan, atau adanya mekanisme suatu sistem. Implementasi bukan sekedar aktivitas, tetapi suatu kegiatan yang terencana dan untuk mencapai tujuan kegiatan ${ }^{7}$. Berdasarkan pengertian-pengertian tersebut dapat disimpulkan bahwa kata penerapan (implementasi) bermuara pada aktifitas, adanya aksi, tindakan, atau mekanisme suatu sistem.

Manajemen adalah suatu proses atau kerangka kerja, yang melibatkan bimbingan atau pengarahan suatu kelompok orang kearah tujuan-tujuan oerganisasional atau maksud-maksud yang nyata. Manajemen adalah suatu kegiatan, pelaksanaannya adalah "managing"pengelolaan_, sedangkan pelaksanaanya disebut dengan manager atau pengelola ${ }^{8}$. Manajemen juga merupakan ilmu

${ }^{5}$ Badudu dkk. Kamus Besar Bahasa Indonesia. Jakarta: Pustaka Sinar Harapan. 2006. hal. 1487

${ }^{6}$ Lukman ali. Kamus Besar Bahasa Indonesia. Jakarta: Balai Pustaka. 2005. hal. 1044 pengetahuan atau seni. Dikatakan sebagai seni adalah suatu pengetahuan bagaimana mencapai hasil yang diinginkan atau dengan kata lain seni merupakan kecakapan yang diperoleh dari pengalamanpengalaman dan pelajaran serta kemampuan untuk menggunakan pengetahuan manajemen. Dalam islam, hakikat manajemen adalah al-tadbir (pengaturan). Kata ini merupakan deviasi dari kata dabbara (mengatur) yang banyak terdapat dalam Al Qur'an.

Manajemen pendidikan adalah suatu kegiatan atau rangkaian kegiatan yang berupa proses pengelolaan usaha kerja sama sekelompok manusia yang tergabung dalam organisasi pendidikan, untuk mencapai tujuan pendidikan yang telah ditetapkan sebelumnya, agar efektif dan efisien ${ }^{9}$. Tak dapat disangkal lagi bahwa manajemen adalah suatu hal penting yang menyentuh, mempengaruhi dan bahkan merasuki hampir seluruh aspek kehidupan manusia layaknya darah dan raga. Juga telah dimengerti bahwa dengan manajemen, manusia mampu mengenalai kemampuannya berikut kelebihannya dan kekurangannya. Begitu juga dalam dimensi pendidikan Islam manajemen telah menjadi sebuah istilah yang tak dapat disiswa. Untuk mencapai tujuannya, maka pendidikan Islam mesti dan harus memiliki manajemen yang baik dan terarah.

Pengertian mengenai mutu pendidikan mengandung makna yang berlainan. Namun, perlu ada suatu pengertian yang operasional sebagai suatu pedoman dalam pengelolaan pendidikan untuk sampai pada pengertian mutu pendidikan, kita lihat terlebih dahulu pengertian mutu pendidikan. Korelasi mutu pendidikan, sebagaimana pengertian yang dikemukan oleh Dzaujak Ahmad. Mutu

${ }^{7}$ Basyiruddin Usman. Media pendidikan. Jakarta: Ciputat Press. 2002

${ }^{8}$ George R. Terry dan Leslie W. Rue, Dasar-Dasar Manajemen, Terj. G.A Ticoalu. Cet

${ }^{9}$ Sulistyorini. Manajemen Pendidikan Islam; Konsep, Strategi, dan Aplikasi. Yogyakarta: TERAS. 2009 hal. 13 
pendidikan adalah kemampuan sekolah dalam pengelolaan secara operasional dan efisien terhadap komponen-komponen yang berkaitan dengan sekolah sehingga menghasilkan nilai tambah terhadap komponen tersebut menurut norma/standar yang berlaku ${ }^{10}$.

Indikator peningkatan mutu atau kriteria yang dapat dijadikan tolok ukur mutu pendidikan yaitu:

a. Hasil akhir pendidikan

b. Hasil langsung pendidikan, hasil langsung inilah yang dipakai sebagai titik tolak pengukuran mutu pendidikan suatu lembaga pendidikan. misalnya tes tertulis, daftar cek, anekdot, skala rating dan skala sikap.

c. Proses pendidikan

d. Instrument input, yaitu alat beritegrasi dengan raw input dan lingkungan

e. Raw input dan lingkungan ${ }^{1111}$.

Dalam proses pendidikan, yang bermutu terlibat berbagai input. Seperti: bahan ajar (kognitif, afektif, atau psikomotorik), metodologi (bervariasi sesuai kemampuan guru), sarana sekolah dukungan administrasi dan sarana prasarana, dan sumber daya lainnya serta penciptaan berbagai input tersebut atau mensinergikan semua komponen dalam interaksi (proses) belajar mengajar baik antara guru, siswa dan sarana pendukung di kelas maupun di luar kelas, baik konteks kurikuler maupun ekstrakurikuler, baik dalam hidup substansi yang akademis maupun yang non akademis dalam suasana yang mendukung proses pembelajaran. Antara proses dan pendidikan yang bermutu saling berhubungan. Akan tetapi agar proses itu tidak salah arah, maka mutu dalam arti hasil output harus dirumuskan terlebih dahulu oleh sekolah, dan jelas target yang akan dicapai untuk setiap tahub

\footnotetext{
${ }^{10}$ Dzauzak Ahmad. Penunjuk Peningkatan Mutu Pendidikan di Sekolah Dasar. Jakarta: Depdikbud 1996, hal. 8

${ }^{11}$ Nurhasan. Konvensi Nasional Pendidikan Indonesia, Kurikulum untuk Abad
}

kurun waktu tertentu. Berbagai input dan proses harus selalu mengacu pada mutu hasil output yang ingin dicapai.

Mutu produk pendidikan akan dipengaruhi oleh sejauh mana lembaga mampu mengelola seluruh potensi secara optimal mulai dari tenaga kependidikan, peserta didik, proses pembelajaran, sarana pendidikan, keuangan dan termasuk hubungannya dengan masyarakat. Pada kesempatan ini, lembaga pendidikan Islam harus semua aktifitas yang beriteraksi didalamnya, seluruhnya mengarah pencapaian pada mutu.

Total Quality Manajement (TQM) merupakan suatu system manajemen yang mengangkat kualitas sebagai strategi usaha yang berorientasi pada kepuasaan pelanggan dengan melibatkan seluruh anggota organisasi. Total Quality Manajement merupakan suatu pendekatan dalam menjalankan usaha yang mencoba untuk memaksimalkan daya saing organisasi melalui perbaikan terus menerus atas produk, jasa, manusia, tenaga kerja, proses, dan lingkungan ${ }^{12}$.

Pengertian dari istilah pendidikan Islam dapat dipahami sebagai pembudayaan dan warisan ajaran agama, budaya, dan peradaban umat Islam dari generasi sepanjang sejarahnya ${ }^{13}$. Beberapa hal yang dapat ditawarkan dalam manajemen mutu pendidikan Islam adalah perbaikan secara terus menerus, menentukan standar mutu, perubahan kultur, perubahan organisasi, dan mempertahankan hubungan dengan pelanggan pendidikan Islam.

Komponen peningkatan mutu pendidikan adalah: 1) kepemimpinan yang berorientasi pada mutu, 2) pendidikan dan pelatihan (diklat), 3) struktur pendukung, 4)

${ }^{12}$ M.N Nasution. Manajemen Mutu Terpadu. Jakarta: Ghalia Indonesia . 2004. HAL. 18

${ }^{13}$ Muhaimin dkk. Paradigma Pendidikan Islam: Upaya Mengefektifkan Pendidikan Agama Islam Sekolahal. Bandung: Remaja Rosdakarya. 2012. hal. 29-30 
komunikasi, 5) reward dan pengakuan, 6) pengukuran.

\section{METODE}

Metode penelitian dapat diartikan sebagai cara ilmiah untuk mendapatkan data dengan tujuan dan kegunaan tertentu ${ }^{14}$. Dengan demikian, maka langkah-langkah yang akan ditempuh oleh peneliti dalam menggali data dan menginterpretasi data guna menemukan jawaban permasalahan yang akan diangkat dalam penelitian ini meliputi langkah-langkah:

a. Pendekatan Penelitian

Penelitian ini adalah penelitian lapangan, yaitu penelitian yang dilakukan secara langsung di lapangan untuk memperoleh data yang diperlukan. Jenis penelitian ini termasuk penelitian kualitatif dengan metode deskriptif analitik yakni menerangkan suatu gejala yang terjadi melalui pencarian fakta dengan interpretasi yang tepat ${ }^{15}$.

b. Lokasi Penelitian

Tempat penelitian dimaksud adalah di Madrasah Aliyah Negeri Kampar. Pemilihan lokasi penelitian ini ditentukan secara sengaja dengan pertimbangan waktu yang relative singkat, biaya yang sedikit, dan tenaga yang efisien karena lokasi tersebut mudah dijangkau oleh peneliti.

c. Subjek dan Objek Penelitian

Subjek dalam penelitian ini adalah Kepala Madrasah dan guru Madrasah Aliyah Negeri Kampar.

d. Data dan Sumber Data

Adapun sumber data penelitian ini adalah Kepala Madrasah, guru, dan tenaga kependidikan Madrasah Aliyah

\footnotetext{
${ }^{14}$ Sugiono. Metode Penelitian Pendidikan; Pendekatan Kuantitatif, Kualitatif, dan $R \& D$. Bandung: Alfabeta. HAL. 3

${ }^{15}$ Mohal. Nasir. Metode Penelitian. Gramedia Indonesia. 1988. HAL. 63
}

Negeri Kampar, serta dokumendokumen atau arsip-arsip Madrasah yang diperlukan serta pihak-pihak lain yang terlibat dalam memberikan informasi yang berhungan dengan penelitian ini.

e. Teknik Pengumpulan Data

Dengan menggunakan metode trianggulasi yaitu menggabungkan metode observasi, wawancara mendalam dan dokumentasi secara berulang-ulang.

1. Observasi, teknik yang digunakan dengan cara melakukan pengamatan langsung dan pencatatan secara sistematis terhadap fenomenafenomena yang diselidiki ${ }^{16}$.

2. Wawancara, teknik pengumpulan data dengan cara tanya jawab sepihak yang dikerjakan dengan sistematis dan berdasarkan tujuan penyelidikan ${ }^{17}$.

3. Dokumentasi yang dapat berbentuk tulisan, gambar, atau karya-karya monumental dari seseorang atau organisasi.

f. Teknik Analisis Data

Kegiatan analisis data adalah proses mencari dan menyusun secara sistematis data yang diperoleh dari hasil observasi, wawancara dan dokumentasi dengan cara mengorganisasikan datadata ke dalam unit-unit untuk dipelajari dan dibuat kesimpulannya.

g. Trianggulasi Data

Teknik pemeriksaan keabsahan data yang telah terkumpul, yang memanfaatkan sesuatu yang lain diluar data itu untuk keperluan pengecekan

\footnotetext{
${ }^{16}$ Masri Singarimbun, et al. Metode Penelitian Survei. Jakarta: LP3ES. 1989. HAL. 60

17 Sutrisno, Hadi. Metode Research II. Yogyakarta: Andi Offet. HAL.136
} 
kembali sebagai pembanding terdapat data tersebut sehingga data yang digunakan terbukti keabsahannya.

\section{PEMBAHASAN}

Penerapan manajemen peningkatan mutu di Madrasah Aliyah Negeri Kabupaten Kampar dijelaskan dalam bentuk poin-poin, yaitu:

a. Kepemimpinan Kepala Madrasah

Kepala Madrasah sebagai educator adalah berusaha memfasilitasi dan memotivasi agar para guru dapat meningkatkan kompetensinya secara terus menerus sehingga pembelajaran dapat berjalan dengan baik.

b. Kepala Madrasah sebagai manajer

Sebagai manajer, kepala Madrasah harus mampu memanaj komponen yang ada di Madrasah, khususnya guru agar mampu meningkatkan dan mengembangkan profesinya.

c. Kepala Madrasah sebagai administrator Peningkatan mutu Madrasah tidak terlepas dari masalah dana, sebagai administrator kepala Madrasah dituntut memiliki kemampuan dalam pengelolaan keuangan.

d. Kepala Madrasah sebagai supervisor

Supervisi yang dilakukan oleh kepala Madrasah adalah melalui kunjungan kelas untuk mengamati proses pembelajaran secara langsung, terutama menilai kompetensi guru dalam pembelajaran.

e. Kepala Madrasah sebagai leader

Gaya kepemimpinan kepala Madrasah sangat menentukan dan besar pengaruhnya dalam pendidikan.

f. Kepala Madrasah sebagai pencipta iklim kerja

Menyusun rencana-rencana kerja dan mengkomunikasikannya dengan guru, dan mengendepankan prinsin-prinsip komunikatif dan azas kebersamaan, serta menerapkan metode reward and punishment (pemberian hadiah dan hukuman).
Manajemen peningkatan mutu Madrasah Aliyah Negeri Kabupaten Kampar, setiap awal tahun pelajaran pasti membuat perencanaan dan program Madrasah. Perencanaan ini juga untuk mencapai target kebahagiaan dunia akhirat. Madrasah sebagai lembaga pendidikan sudah mestinya mempunyai organisasi yang baik agar tujuan pendidikan tercapai sepenuhnya. Adanya pengelompokan dan pembagian kerja yang diterapkan oleh kepala Madrasah bertujuan untuk mewujudkan kesatuan visi dan keterpaduan misi Madrasah.

Pelaksanaan

manajemen peningkatan mutu meliputi beberapa tahap, yaitu: 1) tahap persiapan, yang meliputi penyebaran informasi kepada semua pihak, menyusun tim pengembang dengan melibatkan stakeholder, membentuk tim evaluasi sekolah, menentukan ssaran yang akan dievaluasi. 2) tahap implementasi, yang meliputi pengumpulan informasi, pengolahan informasi, penyusunan buram laporan, dan rekomendasi. 3) tahap tindak lanjut, yang meliputi menganalisis hasil evaluasi, menyusun skala prioritas, menetapkan sasaran dan target sekolah, dan menyusun program kerja untuk meningkatkan mutu sekolah.

$$
\text { Penerapan Total Quality }
$$

Manajement (TQM) dalam manajemen peningkatan mutu Madrasah Aliyah Negeri Kabupaten Kampar, seperti tingkat kelulusan mencapai $100 \%$, banyaknya lulusan yang diterima di perguruan tinggi negeri maupun swasta tidak terlepas dar kerjasama semua pihak, baik itu guru, siswa, orang tua/wali, dan juga kepala Madrasah. Secara umum faktor pendukung yang utama dalam penerapan mutu terpadu adalah kepemimpinan kepala Madrasah, pendidikan dan pelatihan, komunikasi dan evaluasi.

Penerapan Total Quality Manajement (TQM) dalam manajemen peningkatan mutu di Madrasah berpegang pada prinsip-prinsip:

a. fokus terhadap pelanggan, dengan proses pelayanan atau penyelenggaraan 
pendidikan yang baik sesuai keinginan pelanggannya dan lulusannya dapat diterima di lembaga pendidikan yang diinginkan dan dapat juga menciptakan lapangan kerja.

b. perbaikan proses, adalah perbaikan secara terus menerus secara individual maupun secara berkelompok baik didalam menyeting kualitas sekolah dengan jalan administrator bekerja berkolaborasi dengan pelanggan dan para guru.

c. keterlibatan total, setiap komponen yang terdapat di Madrasah, masing-masing memiliki peran dan tanggungjawab yang sama dalam upaya pencapaian visi dan misi Madrasah.

Manajemen peningkatan mutu di Madrasah Aliyah Negeri Kabupaten Kampar dinilai sudah cukup baik, baik dalam hal perencanaannya, pengorganisasian, pelaksanaan maupun pengawasan dan evaluasinya. Sehingga mutu pendidikan di Madrasah Aliyah Negeri Kabupaten Kampar terus mengalami peningkatan, baik dilihat dari proses pembelajaran maupun dari persentase kelulusannya. Dalam upaya peningkatan mutu pendidikan ada kekuatan, kelemahan, peluang dan tantangan.

\section{Prinsip-prinsip Total Quality}

Manajement (TQM) ternyata tidak serta merta mendongkrak peningkatan kinerja pelaksana sekolah yang implikasinya dapat meningkatkan kompetensi siswa. Menurut penulis, yang paling pertama diperbaiki adalah budaya kerja, unjuk kerja dan disiplin dari pelaksana sekolah (guru, karyawan dan kepala Madrasah). Semuanya harus memandang siswa sebagai pelanggan, yang harus dilayani dengan sebaik-baiknya demi kepuasaan mereka. Pelaksana sekolah selalu bersemangat untuk maju, bersemangat terus untuk menambah kemampuan dan keterampilannya yang pada akhirnya akan meningkatkan unjuk kerja mereka dihadapan siswa.

\section{PENUTUP}

\section{Simpulan}

Manajemen peningkatan mutu Madrasah Aliyah Negeri Kabupaten Kampar, yaitu: 1) perencanaan, 2) pengorganisasian, 3) pelaksanaanya, 4) pengawasan. Faktor-faktor yang mendukung penerapan manajemen peningkatan mutu di Madrasah Aliyah Negeri Kabupaten Kampar adalah 1) sarana dan prasarana sekolah, 2) pengalaman kerja, 3) komunikasi.

a. Kepemimpinan Kepala Madrasah

Kepala Madrasah sebagai educator adalah berusaha memfasilitasi dan memotivasi agar para guru dapat meningkatkan kompetensinya secara terus menerus sehingga pembelajaran dapat berjalan dengan baik.

b. Kepala Madrasah sebagai manajer

Sebagai manajer, kepala Madrasah harus mampu memanaj komponen yang ada di Madrasah, khususnya guru agar mampu meningkatkan dan mengembangkan profesinya.

c. Kepala Madrasah sebagai administrator Peningkatan mutu Madrasah tidak terlepas dari masalah dana, sebagai administrator kepala Madrasah dituntut memiliki kemampuan dalam pengelolaan keuangan.

d. Kepala Madrasah sebagai supervisor Supervisi yang dilakukan oleh kepala Madrasah adalah melalui kunjungan kelas untuk mengamati proses pembelajaran secara langsung, terutama menilai kompetensi guru dalam pembelajaran.

e. Kepala Madrasah sebagai leader

Gaya kepemimpinan kepala Madrasah sangat menentukan dan besar pengaruhnya dalam pendidikan.

f. Kepala Madrasah sebagai pencipta iklim kerja

Menyusun rencana-rencana kerja dan mengkomunikasikannya dengan guru, dan mengendepankan prinsin-prinsip komunikatif dan azas kebersamaan, serta menerapkan metode reward and 
punishment (pemberian hadiah dan hukuman).

\section{Saran}

a. Perlu ditingkatkan etos kerja, motivasi, kerjasama tim, moral kerja yang baik, punya rasa memiliki, mau bekerja keras dan komitmen yang tinggi dari seluruh jajaran Tim Manajemen Madrasah Aliyah Negeri Kabupaten Kampar agar upaya peningkatan mutu pendidikan dapat berjalan secara optimal.

b. Mutu bukanlah sesuatu yang terjadi secara tiba-tiba dan muncul dihadapan para guru, karyawan dan kepala Madrasah. Mutu harus direncanakan, karena itu ada trilogy mutu, yaitu perencanaan mutu, pengawasan mutu dan perbaikan mutu.

c. Dalam implementasi manajemen mutu terpadu disekolah, hendaknya memperhatikan prinsip, syarat-syarat dan empat pilar TQM sehingga pelaksanaannya dapat berlangsung dengan lancar.

d. Hendaknya Madrasah/Sekolah mulai mengimplementasikan manajemen mutu terpadu untuk meningkatkan kualitas pendidikan di Indonesia

\section{DAFTAR PUSTAKA}

Badudu dkk. 2006. Kamus Besar Bahasa Indonesia. Jakarta: Pustaka Sinar Harapan

Basyiruddin Usman. 2002. Media pendidikan. Jakarta: Ciputat Press.

Behling dkk. 1984. dalam materi pelatihan keterampilan manajerial SPMK. Tersedia:HTTP//kmpk.ugm.ac.id./d ata/SPMKK/5a-KEPEMIMPINAN (revDes'02)

Dzauzak Ahmad. 1999. Penunjuk Peningkatan Mutu Pendidikan di Sekolah Dasar. Jakarta: Depdikbud.
E. Mulyasa.2005. Menjadi Kepala Sekolah Profesional dalam Menyukseskan $M B S$ dan KBK (Bandung: PT. Remaja Rosdakarya.

George R. Terry dan Leslie W. Rue, DasarDasar Manajemen, Terj. G.A Ticoalu. Cet

Husbullah. 2006. Otonomi Pendidikan: Kebijakan Otonomi Daerah dan Implikasinya terhadap Penyelenggaraan Pendidikan. Jakarta: PT. Rajagrafindo Persada.

Lukman ali. 2005. Kamus Besar Bahasa Indonesia. Jakarta: Balai Pustaka.

Masri Singarimbun. 1989. et al. Metode Penelitian Survei. Jakarta: LP3ES.

M.N Nasution. 2004. Manajemen Mutu Terpadu. Jakarta: Ghalia Indonesia.

Muhaimin dkk. 2012. Paradigma Pendidikan Islam: Upaya Mengefektifkan Pendidikan Agama Islam Sekolah. Bandung: Remaja Rosdakarya.

Moh. Nasir. 1988. Metode Penelitian. Gramedia Indonesia.

Nurhasan. Konvensi Nasional Pendidikan Indonesia, Kurikulum untuk Abad

Sugiono. 2009. Metode Penelitian Pendidikan; Pendekatan Kuantitatif, Kualitatif, dan $R \& D$. Bandung: Alfabeta.

Sulistyorini. 2009. Manajemen Pendidikan Islam; Konsep, Strategi, dan Aplikasi. Yogyakarta: TERAS.

Sutrisno, Hadi. Metode Research II. Yogyakarta: Andi Offet.

Syafarudin. 2002. Manajemen Mutu Terpadu dalam Pendidikan. Jakarta: Grasindo. 